\title{
Icaritin enhances the efficacy of cetuximab against triple-negative breast cancer cells
}

\author{
LI YIN $^{1,2^{*}}$, XIAO-WEI QI ${ }^{3 *}$, XUN-ZHOU LIU ${ }^{4 *}$, ZE-YU YANG $^{1,2}$, RUI-LI CAI $^{1,2}$, \\ HONG-JUAN CUI ${ }^{4}$, LI CHEN ${ }^{3,4}$ and SHI-CANG YU ${ }^{1,2,4}$ \\ ${ }^{1}$ Department of Stem Cell and Regenerative Medicine, Institute of Pathology and Southwest Cancer Center, \\ Southwest Hospital, Third Military Medical University (Army Medical University); \\ ${ }^{2}$ Key Laboratory of Cancer Immunopathology, Ministry of Education; ${ }^{3}$ Breast Disease Center, Southwest Hospital, \\ Third Military Medical University (Army Medical University), Chongqing 400038; \\ ${ }^{4}$ State Key Laboratory of Silkworm Genome Biology, Southwest University, Chongqing 400715, P.R. China
}

Received January 16, 2019; Accepted November 29, 2019

DOI: 10.3892/ol.2020.11496

\begin{abstract}
Triple-negative breast cancer (TNBC) has a greater risk of recurrence and metastasis along with a worse prognosis compared with other subtypes of breast cancer. Studies have revealed that mitogenic estrogen signaling is involved in the malignant proliferation of TNBC cells through a novel variant of the estrogen receptor, estrogen receptor $\alpha-36$ (ER- $\alpha 36)$. The results of the present study demonstrated that knockdown of ER- $\alpha 36$ expression in TNBC cells using short hairpin RNA inhibited rapid estrogen signaling bypass activation of the PI3K/AKT signaling pathway. Moreover, the ER- $\alpha 36$ modulator icaritin inhibited the proliferation of TNBC cells both in vitro and in vivo. Here, it was revealed that the combination of icaritin and cetuximab, a therapeutic epidermal growth factor receptor (EGFR) neutralizing antibody, induced apoptosis and inhibited cell proliferation synergistically in TNBC cells. The results of the present study improved the understanding of the underlying mechanisms of TNBC progression and supported
\end{abstract}

Correspondence to: Dr Shi-Cang Yu, Department of Stem Cell and Regenerative Medicine, Institute of Pathology and Southwest Cancer Center, Southwest Hospital, Third Military Medical University (Army Medical University), 30 Gaotanyan Street, Chongqing 400038, P.R. China

E-mail: yushicang@163.com

Dr Li Chen, Breast Disease Center, Southwest Hospital, Third Military Medical University (Army Medical University), 30 Gaotanyan Street, Chongqing 400038, P.R. China

E-mail: lichen2007@126.com

*Contributed equally

Key words: estrogen receptor $\alpha-36$, epidermal growth factor receptor, icaritin, cetuximab, triple-negative breast cancer the therapeutic potential of combined treatment targeting the ER- $\alpha 36$ and EGFR.

\section{Introduction}

Breast cancer (BC) was one of the most common types of cancer in US women in 2017 (1). Among the different subtypes, triple-negative breast cancer (TNBC) is defined by the absence of expression of the estrogen receptor (ER), progesterone receptor and the human epidermal growth factor receptor- 2 or gene amplification $(2,3)$. These biologic characteristics confer TNBC with greater aggressiveness and relapse risk along with a worse prognosis compared with other subtypes of BC $(4,5)$. Limited options for systemic treatment exist for BC other than chemotherapy (6). BC heterogeneity has limited the successful development of targeted therapy (7). Currently, there are no approved targeted therapies for TNBC (8).

The epidermal growth factor receptor (EGFR) is essential for ductal morphogenesis during the development of normal mammary glands (9) and its upregulation in $\mathrm{BC}$ has been well documented (10). Previously, researchers report that the EGFR is commonly upregulated in TNBC compared with other BC subtypes and is associated with poor prognosis (11-13). EGFR inhibition is a promising approach for TNBC; however, minimal benefits have been observed by targeting TNBC in clinical studies $(14,15)$. The molecular mechanisms for the insensitivity of EGFR targeted therapy in patients with TNBC remain unclear (16).

Previously, Wang et al (17) reported a novel ER variant with a molecular weight of $36 \mathrm{kDa}, \mathrm{ER}-\alpha 36$, which is located mainly in the plasma membrane and cytoplasm. ER- $\alpha 36$ differs from the estrogen receptor $\alpha-66$ (ER- $\alpha 66$ ) as it lacks both transcriptional activation domains [Activation factor (AF)-1 and AF-2], but has the DNA-binding domain and partial ligand-binding domains. ER- $\alpha 36$ possesses a unique 27 amino acid domain that replaces the last 138 amino acids encoded by exons 7 and 8 of the ER- $\alpha 66$ gene. ER- $\alpha 36$ lacks intrinsic transcription ability, but mediates non-genomic estrogen signaling. ER-a36 is generated from a promoter located in the first intron of the 
ER- $\alpha 66$ gene, indicating that ER- $\alpha 36$ expression is regulated independently from ER- $\alpha 66$. This is consistent with the findings that ER- $\alpha 36$ is expressed in cancer tissue specimens from patients with ER-negative BC and established ER-negative BC cells that lack ER- $\alpha 66$ expression $(18,19)$. It has been suggested that ER- $\alpha 36$ may mediate rapid estrogen signaling, which serves a role in anti-estrogen drug resistance in ER-positive $\mathrm{BC}$ and in chemotherapy resistance in ER-negative BC (20). ER- $\alpha 36$ mediates rapid estrogen and antiestrogen signaling and stimulates cell proliferation through the activation of the mitogen-activated protein kinase (MAPK/ERK) and the PI3K/AKT signaling pathways (21).

Icaritin is a prenylflavonoid derivative from the genus Epimedium that has been used in traditional Chinese medicine for centuries (22). Studies have demonstrated that icaritin can be used against different types of cancer. Icatrin can inhibit the proliferation and enhance the radio-sensitivity of BC cells (23); induce apoptosis of human endometrial cancer cells (24); and exhibit potent proliferation inhibition in chronic myeloid leukemia and suppress the growth of renal carcinoma cells (25). Recently, Wang et al (26) demonstrated that icaritin can decrease the expression of the ER- $\alpha 36$ protein in TNBC cells. Thus, it was speculated that the combined application of icaritin and the EGFR inhibitor for patients with TNBC may achieve improved results compared with the individual use of either drug.

In the present study, the function of the ER- $\alpha 36$ in EGFR targeted therapy-resistant TNBC was investigated. Furthermore, the efficiency of combination therapy with ER- $\alpha 36$ molecular inhibitor icaritin and EGFR inhibitor cetuximab for TNBCs was also evaluated.

\section{Materials and methods}

Ethical approval. The study protocol was approved by the Animal Care and Use Committee of Third Military Medical University (Army Medical University, Chongqing, China).

Chemicals and antibodies. E2 $\beta$ was purchased from Merck $\mathrm{KGaA}$. The polyclonal anti-ER- $\alpha 36$ antibody was generated and characterized as described previously (14). Antibodies against EGFR (cat. no. 4267), ER- $\alpha 66$ (cat. no. 13258), glyceraldehyde 3-phosphate dehydrogenase (cat. no. 2118), AKT (cat. no. 9272), GAPDH (cat. no. 2118) and phospho-Akt (Ser473; cat. no. 4060) were all obtained from Cell Signaling Technology, Inc. Icaritin was purchased from Shenogen Pharma Group, Ltd., and cetuximab was obtained from Merck KGaA.

Culture and treatment of cells. MCF-7, MDA-MB-231 and MDA-MB-436 cell lines were purchased from American Type Culture Collection. The MDA-MB-231 cell line is a well known cell line of highly aggressive, invasive and poorly differentiated TNBC established in 1978 (27,28). The MDA-MB-436 cell line is also well known and possesses BRCA1 mutations (29). These cell lines were chosen as they are well studied, their behavior is highly predictable. The cells were maintained in DMEM containing $10 \%$ fetal calf serum and $1 \%$ penicillin/streptomycin (DMEM and fetal calf serum were purchased from HyClone; GE Healthcare Life Sciences and penicillin/streptomycin were purchased from Thermo Fisher Scientific, Inc.) at $37^{\circ} \mathrm{C}$ in an incubator containing $5 \% \mathrm{CO}_{2}$. Prior to treatment with E2 $\beta$ and icaritin, cells were transferred to phenol red-free medium containing $2.5 \%$ charcoal-stripped fetal calf serum (HyClone; GE Healthcare Life Sciences) and maintained for $24 \mathrm{~h}$.

Establishment of stable cell lines. MDA-MB-231 and MDA-MB-436 cell lines with the ER- $\alpha 36$ expression knockdown using the short-hairpin (sh) RNA method were established as described previously (30). The ER- $\alpha 36$ shRNA plasmid, vehicle plasmid (pRNAT-U6.1/Neo) and anti-ER- $\alpha 36$ antibody were provided by Dr. Zhao-yi Wang (Department of Medical Microbiology and Immunology, Creighton University Medical School). Transfection of the plasmids were performed after cell confluency reached $60 \%$ within $24 \mathrm{~h}$ of seeding. Transfection reagent Lipofectamine ${ }^{\circledR} 3000$ (Invitrogen; Thermo Fisher Scientific, Inc.) was used for plasmid transfection according to the manufacturer's instructions. A total of $10 \mu \mathrm{g}$ plasmid $/ 1 \times 10^{6}$ cells was incubated for $12 \mathrm{~h}$ at $37^{\circ} \mathrm{C}$ in a humidified atmosphere with $5 \% \mathrm{CO}_{2}$. At $48 \mathrm{~h}$ post-transfection, the appropriate antibiotic (neomycin; Sigma-Aldrich; Merck $\mathrm{KGaA}$ ) was used to screen the transfected cell lines for 3 weeks, and $>20$ clones of selected cells were pooled and termed MDA-MB-231/V and MDA-MB-231/Sh36 or MDA-MB-436/V and MDA-MB-436/Sh36, respectively. The efficiency of ER- $\alpha 36$ shRNA plasmid transduction was determined by western blotting using anti-ER- $\alpha 36$ antibody $(1: 1,000)$.

Cell proliferation assay. Cells were seeded in 60-mm petri dishes at a final concentration of $5 \times 10^{4}$ cells/dish. After $24 \mathrm{~h}$, the indicated concentrations of cetuximab $(1,5,10,50$ and $100 \mu \mathrm{g} / \mathrm{ml})$, icaritin $(1,2.5,5,7.5$ and $10 \mu \mathrm{M})$, cetuximab $(100 \mu \mathrm{g} / \mathrm{ml})+$ icaritin $(1,2.5,5,7.5$ and $10 \mu \mathrm{M})$ or control DMSO were added. After 7 days of culture, cell numbers were determined using the Countess II Automated Cell Counter (Thermo Fisher Scientific, Inc). All cells were maintained at $37^{\circ} \mathrm{C}$ and $5 \% \mathrm{CO}_{2}$ in a humidified incubator.

Western blotting. Cells were washed twice with cold phosphate-buffered saline (PBS) and extracted on ice with RIPA buffer (Beyotime Institute of Biotechnology) containing 1\% phenylmethane sulfonyl fluoride and $1 \%$ phosphatase inhibitor cocktail solution (Beyotime Institute of Biotechnology). Protein concentrations were quantified using a Bicinchoninic Acid Protein Assay kit (Bio-Rad Laboratories, Inc.). Cell lysates were boiled for $5 \mathrm{~min}$ in sodium dodecyl sulfate gel-loading buffer and stored at $-20^{\circ} \mathrm{C}$ for western blotting. Cell lysates containing $50 \mu \mathrm{g}$ protein were separated using $10 \%$ sodium dodecyl sulfate-polyacrylamide gel electrophoresis and transferred to polyvinylidene fluoride (PVDF) membranes (EMD Millipore). PVDF membranes were blocked for $1 \mathrm{~h}$ at room temperature with $5 \%$ non-fat milk, and incubated with primary antibody diluted $(1: 1,000)$ in $5 \%$ non-fat milk overnight at $4^{\circ} \mathrm{C}$. Next, the membranes were incubated with horseradish peroxidase-conjugated secondary antibody (Cell Signaling Technology, Inc.; 1:4,000) at room temperature for $1 \mathrm{~h}$ and developed using an ECL Western Blotting Analysis System (GE Healthcare). 
GAPDH was used as the control. The density of the immunoreactive bands was quantified using Image J V1.8 (National Institutes of Health).

Flow cytometry. Cells $\left(2 \times 10^{5} /\right.$ well) in 6 -well plates were treated with the indicated concentrations of cetuximab, icaritin, cetuximab + icaritin or control DMSO were added for $24 \mathrm{~h}$, collected and washed twice in ice-cold PBS. The apoptosis assay was conducted using an Annexin V-FITC apoptosis detection Kit (Beyotime Institute of Biotechnology) according to the manufacturer's instructions and a BD Accuri ${ }^{\mathrm{TM}}$ C6 Flow Cytometer (Becton, Dickinson and Company) was used for fluorescence detection. The results were analyzed using FlowJo 7.6 software (Becton, Dickinson and Company).

Construction of an orthotopic mouse model of BC. A suspension of MDA-MB-231 and MDA-MB-436 cells in a PBS-Matrigel ( $\mathrm{v} / \mathrm{v}, 1: 1)$ solution was implanted in the mammary fat pads of female NOD/SCID mice $(n=40$; age, 4-6 weeks; and weight: 18-20 g) obtained from the Animal Center of the Third Military Medical University. Each mouse was inoculated with $1 \times 10^{6}$ tumor cells. The tumor volume was calculated as length $\mathrm{x}$ width $2 / 2$. After the tumors had reached 6-8 $\mathrm{mm}$ in diameter, mice were grouped randomly (5 per group) and injected (i.v.) with control $(0.9 \% \mathrm{NaCl})$, cetuximab ( $2 \mathrm{mg} / \mathrm{kg} /$ week), icaritin $(50 \mathrm{mg} / \mathrm{kg} /$ week $)$ or cetuximab + icaritin (equivalent dose/week). According to the guidelines of IACUC, the mice were euthanized within $48 \mathrm{~h}$ when the diameter of the xenografts reached $1.5 \mathrm{~cm}$.

Statistical analyses. All assays were repeated at least 3 times. Data were described as the mean \pm standard deviation (SD) or standard error of mean (SEM) as indicated. Two-sided paired Student's t-tests were used to compare the differences between two groups. One-way ANOVA was used for the comparison of multiple groups, followed by the Bonferroni's post-hoc test. Statistical analyses were performed using SPSS v.19 (IBM Corp). P $<0.05$ was considered to indicate a statistically significant difference.

\section{Results}

High expression of ER- $\alpha 36$ activates the PI3K/AKT signaling pathway downstream of the estrogen receptor. MDA-MB-231 and MDA-MB-436 cell lines expressed high levels of ER- $\alpha 36$ and EGFR compared with MCF7 of ER-positive cell, but undetectable levels of the full length ER- $\alpha$ (Fig. 1A). Following treatment with increasing concentrations of E2 $\beta$ in MDA-MB-231 and MDA-MB-436 cells, western blotting was conducted with a phosphorylation-specific anti-AKT antibody. Basal AKT phosphorylation was notably increased in MDA-MB-231 and MDA-MB-436 cells, particularly at E2 $\beta 1 \mu \mathrm{M}$ concentration (Fig. 1B). To determine if ER- $\alpha 36$ mediated the activation of mitogenic estrogen signaling in these TNBC cell lines, a stable knockdown of ER- $\alpha 36$ cells by shRNA in MDA-MB-231 and MDA-MB-436 cells was performed. Western blotting demonstrated that ER- $\alpha 36$ expression was down-regulated by $\sim 80 \%$ in shRNA-transfected cells compared with control cells (Fig. 1C). E2 $\beta$ treatment failed to induce AKT phosphorylation in the MDA-MB-231 cell line following ER- $\alpha 36$ knockdown. Similar results were observed in the MDA-MB-436 ER- $\alpha 36-$ knockdown cell line (Fig. 1D). These results suggested that estrogen may activate the downstream PI3K/AKT signaling pathway through ER- $\alpha 36$.

Icaritin downregulates the expression of ER- $\alpha 36$ and inhibits E2 $\beta$-stimulated AKTphosphorylation. The structure of icaritin was shown in Fig. 2A. Western blotting revealed that icaritin treatment potently reduced ER- $\alpha 36$ expression in both TNBC cell lines (Fig. 2B). The EGFR inhibitor cetuximab was used to treat MDA-MB-231 and MDA-MB-436 cells for $30 \mathrm{~min}$ prior to stimulation with EGF and E2 $\beta$. EGF-stimulated AKT phosphorylation was inhibited by the EGFR inhibitor cetuximab, however, cetuximab failed to influence E2 $\beta$-stimulated AKT phosphorylation in the two TNBC cancer cell lines (Fig. 2C). In icaritin-treated E2 $\beta$-stimulated TNBC cells, AKT phosphorylation was inhibited (Fig. 2C and D). These results suggested that E- $\alpha 36$-mediated activation of the estrogen signaling pathway may be associated with EGFR-targeted treatment failure in TNBC cells.

Cetuximab plus icaritin inhibits TNBC cell proliferation and induces apoptosis. To determine whether the effects of the combined application of cetuximab and icaritin on the proliferation of TNBC cells were stronger compared with cetuximab or icaritin treatment alone, different concentrations of cetuximab were tested in MDA-MB-231 cells. The quantity of MDA-MB-231 cells did not decrease significantly, even in the highest dose group of $100 \mu \mathrm{g} / \mathrm{ml}$ cetuximab (Fig. 3A). Next, MDA-MB-231 cell were treated with different concentrations of icaritin, and the mean percentages of cells were $1 \mu \mathrm{M}, 99.09 \pm 4.80 \% ; 2.5 \mu \mathrm{M}, 93.99 \pm 6.62 \% ; 5 \mu \mathrm{M}$, $83.52 \pm 6.77 \% ; 7.5 \mu \mathrm{M}, 66.4 \% \pm 5.658$ and $10 \mu \mathrm{M}, 41.35 \pm 7.00 \%$ (Fig. 3A). To identify the combined effects, MDA-MB-231 cells were treated with cetuximab + icaritin; the mean percentages of cells were as follows: $100 \mu \mathrm{g} / \mathrm{ml}$ cetuximab + $1 \mu \mathrm{M}$ icaritin, $94.45 \pm 6.58 \% ;, 100 \mu \mathrm{g} / \mathrm{ml}$ cetuximab $+2.5 \mu \mathrm{M}$ icaritin, $81.84 \pm 4.55 \% ; 100 \mu \mathrm{g} / \mathrm{ml}$ cetuximab $+5 \mu \mathrm{M}$ icaritin, $66.01 \pm 8.75 \% ; 100 \mu \mathrm{g} / \mathrm{ml}$ cetuximab $+7.5 \mu \mathrm{M}$ icaritin, $47.32 \pm 5.82 \%$; and $100 \mu \mathrm{g} / \mathrm{ml}$ cetuximab $+10 \mu \mathrm{M}$ icaritin, $22.99 \pm 4.05 \%$ (Fig. 3A). The combined administration of icaritin and cetuximab was more effective in inhibiting the proliferation of MDA-MB-231 cells at $100 \mu \mathrm{g} / \mathrm{ml}$ cetuximab $+2.5 \mu \mathrm{M}$ icaritin compared with icaritin or cetuximab alone (Fig. 3A). Similarly, the combination strategy significantly reduced the mean percentages of cells compared with single drug treatment in MDA-MB-436 cells (Fig. 3A). These results suggested that once the EGFR and ER signaling pathways were suppressed simultaneously, the proliferation of TNBC cells was inhibited more potently.

To ascertain whether this inhibition was caused by apoptosis, the Annexin V/PI double labeling apoptosis assay was performed. The percentages of apoptotic cells in the combination groups were as follows: $100 \mu \mathrm{g} / \mathrm{ml}$ cetuximab $+5 \mu \mathrm{M}$ icaritin, 24.35 $\pm 2.14 \% ; 100 \mu \mathrm{g} / \mathrm{ml}$ cetuximab $+7.5 \mu \mathrm{M}$ icaritin, $39.85 \pm 2.26 \%$; and $100 \mu \mathrm{g} / \mathrm{ml}$ cetuximab $+10 \mu \mathrm{M}$ icaritin, $48.19 \pm 3.34 \%$, which were higher compared with the cetuximab alone treatment group $(21.47 \pm 1.81 \%)$ or icaritin gradient treatment group $(5 \mu \mathrm{M}$ icaritin, $17.80 \pm 1.15 \% ; 7.5 \mu \mathrm{M}$ icaritin, 
A

B

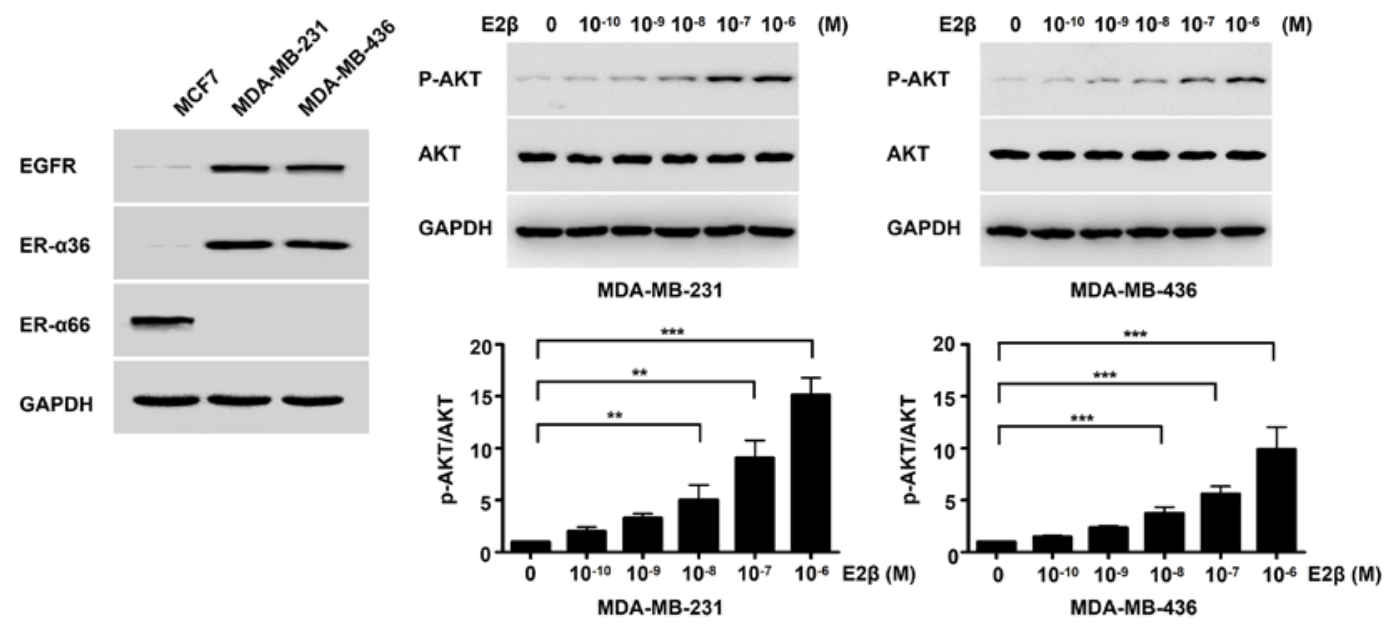

C
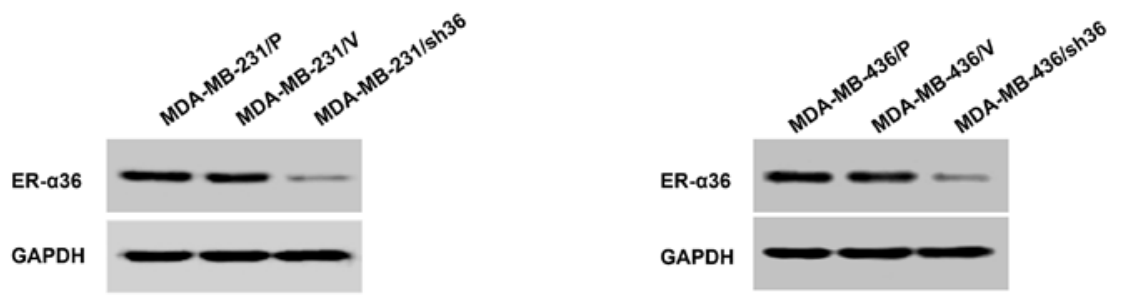

D
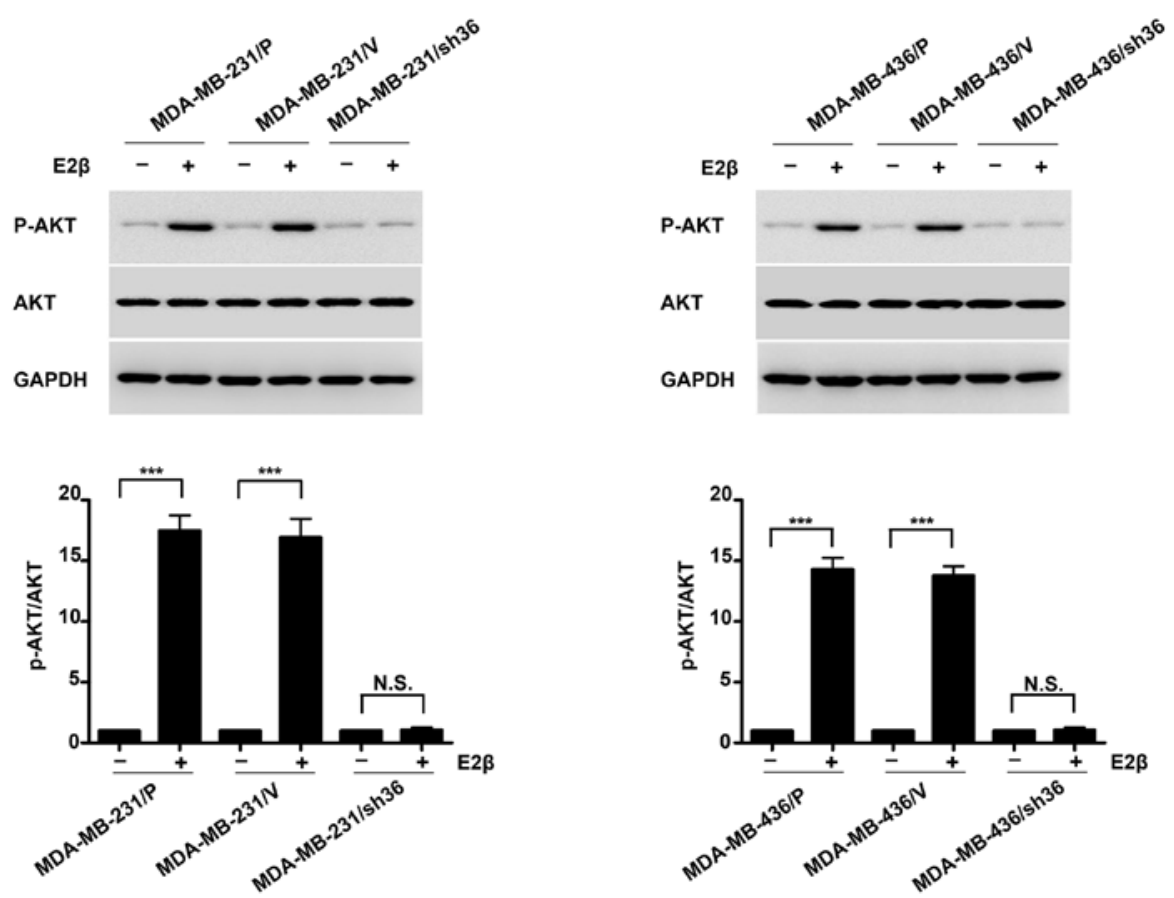

Figure 1. High expression of ER- $\alpha 36$ mediates estrogen signaling via the PI3K/AKT signaling pathway in TNBC cells. (A) Western blots displaying the expression of ER- $\alpha 66$, ER- $\alpha 36$ and EGFR in an ER-positive breast-cancer cell line (MCF7) and TNBC cell lines (MDA-MB-231 and MDA-MB-436). (B) MDA-MB-231 and MDA-MB-436 cells were treated with different concentrations (M) of estrogen for 30 min, and AKT phosphorylation levels were investigated by western blotting. (C) Western blots representing ER- $\alpha 36$ expression in variants of MDA-MB-231 and MDA-MB-436 cells; parental cells, MDA-MB-231/P and MDA-MB-436/P; control cells transfected with the empty vector, MDA-MB-231/V and MDA-MB-436/V; and ER- $\alpha 36$ expression knockdown cells, MDA-MB-231/sh36 and MDA-MB-436/sh36. (D) Western blots representing the effects of E2 $\beta$ ( $1 \mu \mathrm{M})$ on the phosphorylation and expression of AKT in variants of MDA-MB-231 and MDA-MB-436 cells, as well as the fold-change of p-AKT/AKT. GAPDH was used as a loading control. Data are presented as the mean \pm SEM from three independent experiments. ${ }^{* * *} \mathrm{P}<0.01$ and ${ }^{* * * *} \mathrm{P}<0.001$. ER- $\alpha 36$, estrogen receptor $\alpha-36$; ER- $\alpha 66$, estrogen receptor $\alpha-66$; EGFR, epidermal growth factor receptor; TNBC, triple negative breast cancer; E2 $\beta$, 17 $\beta$-estradiol; p, phosphorylated.

$27.45 \pm 2.06 \% ; 10 \mu \mathrm{M}$ icaritin, 33.85 $\pm 2.53 \%$ ) (Fig. 3B and C). Similar results were also obtained using the MDA-MB-436 cell line (Fig. 3B and C). Together, these results demonstrated that the combination of cetuximab and icaritin may more effectively promote the apoptosis of TNBC cells compared with either drug used alone. (Fig. 3B and C). 
A<smiles>COc1ccc(-c2oc3c(CC=C(C)C)c(O)cc(O)c3c(=O)c2O)cc1</smiles>

Icaritin

C
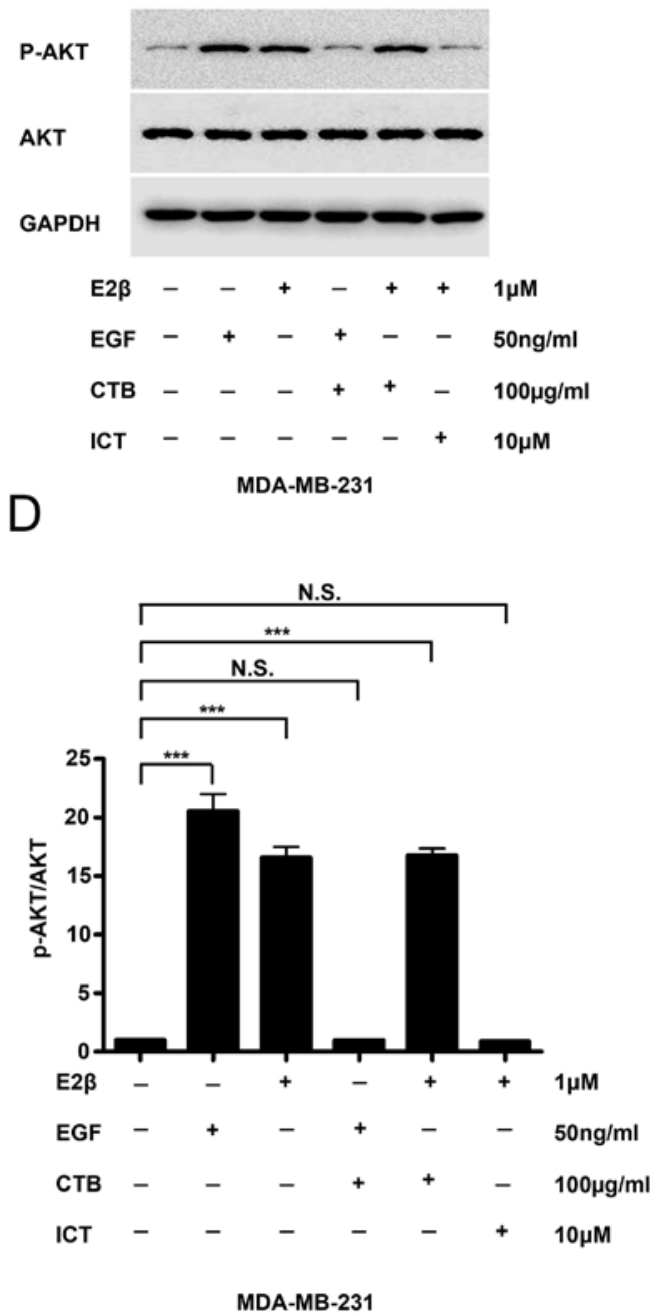

B

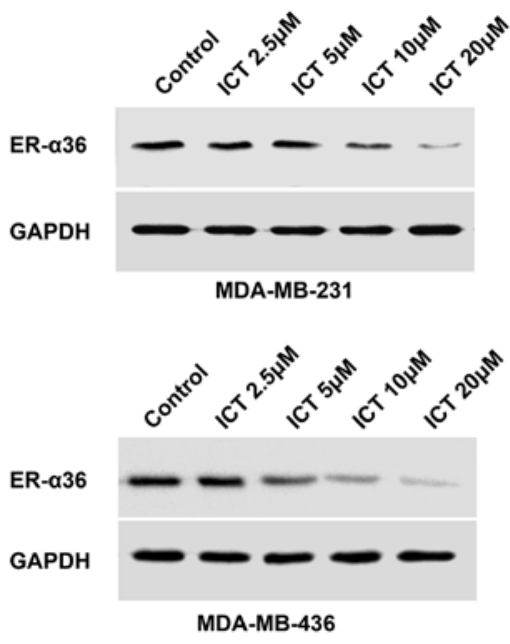

P-AKT

AKT

GAPDH

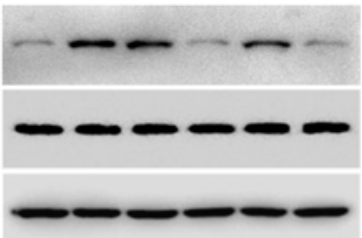

$\mathrm{E} 2 \beta-++-++1 \mu \mathrm{M}$

EGF - + - + - $-50 \mathrm{ng} / \mathrm{m}$

СТВ - $-\ldots++-100 \mu \mathrm{g} / \mathrm{ml}$

ICT - $-\quad-\quad+\quad+10 \mu \mathrm{M}$

MDA-MB-436

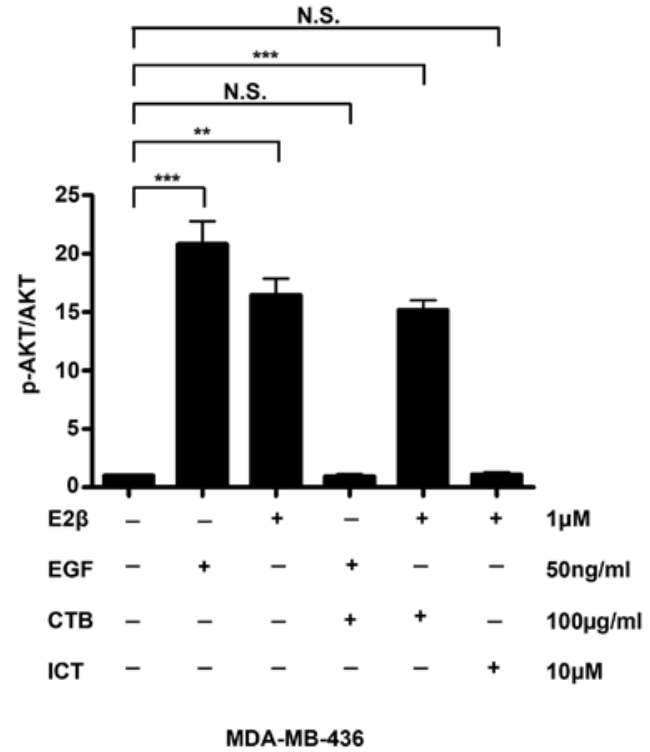

Figure 2. ICT down-regulates ER- $\alpha 36$ expression and inhibits E2 $\beta$-stimulated AKT phosphorylation. (A) Chemical structure of ICT. (B) Western blots of ER- $\alpha 36$ expression in MDA-MB-231 and MDA-MB-436 cells treated with different concentrations (M) of icaritin for $12 \mathrm{~h}$. (C) Western blots demonstrating the effects of $\mathrm{E} 2 \beta(1 \mu \mathrm{M})$ or EGF $(50 \mathrm{ng} / \mathrm{ml})$ on the phosphorylation and expression of AKT in MDA-MB-231 and MDA-MB-436 cells treated with $10 \mu \mathrm{M}$ of ICT or $100 \mu \mathrm{g} / \mathrm{ml}$ of CTB for $12 \mathrm{~h}$, and (D) fold change of p-AKT/AKT. GAPDH was used as a loading control. Data presented as mean \pm SEM obtained from three independent experiments. ${ }^{* *} \mathrm{P}<0.01$ and ${ }^{* * * *} \mathrm{P}<0.001$. CTB, cetuximab; ICT, icaritin; ER- $\alpha 36$, estrogen receptor $\alpha-36$; EGF, epidermal growth factor; E2 $\beta$, $17 \beta$-estradiol; p, phosphorylated.

Therapeutic effects of the combined treatment with cetuximab andicaritin on TNBC cells in vivo. To evaluate the effects of cetuximab monotherapy, icaritin monotherapy and combined treatment on TNBC cells in MDA-MB-231 and MDA-MB-436 xenografts, human $\mathrm{BC}$ cell xenografts were created in immunocompromised NOD/SCID mice using MDA-MB-231 or MDA-MB-436 
A
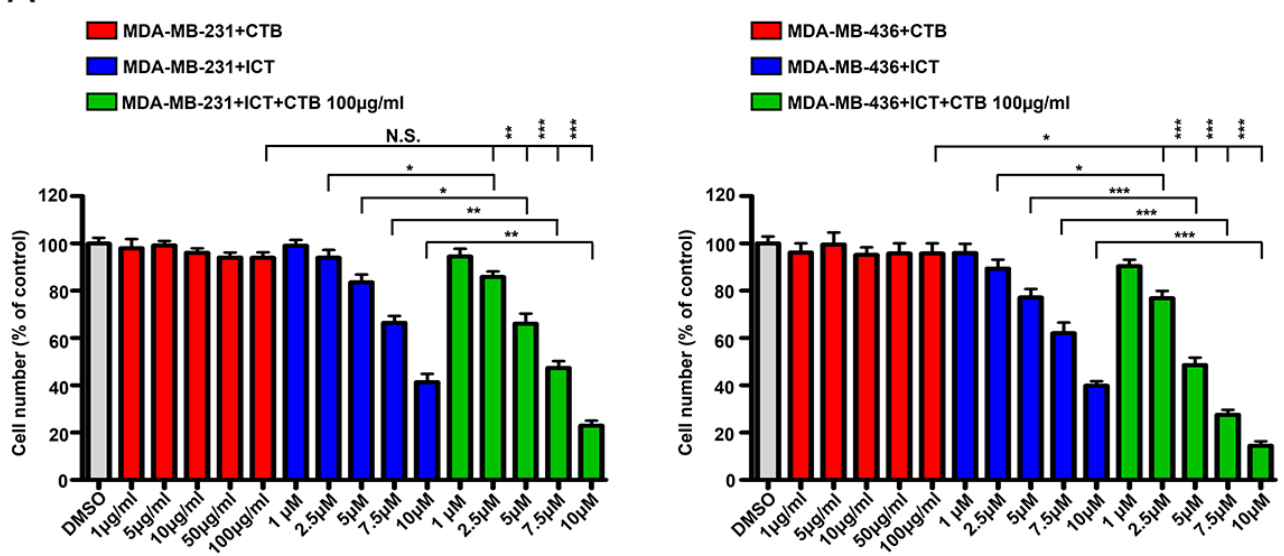

B
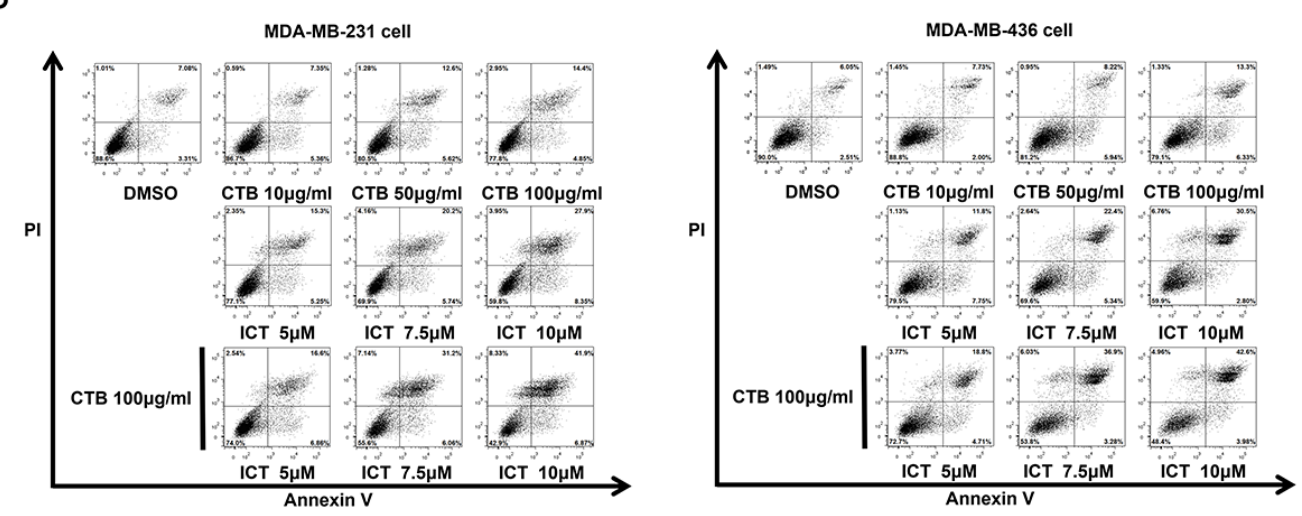

C
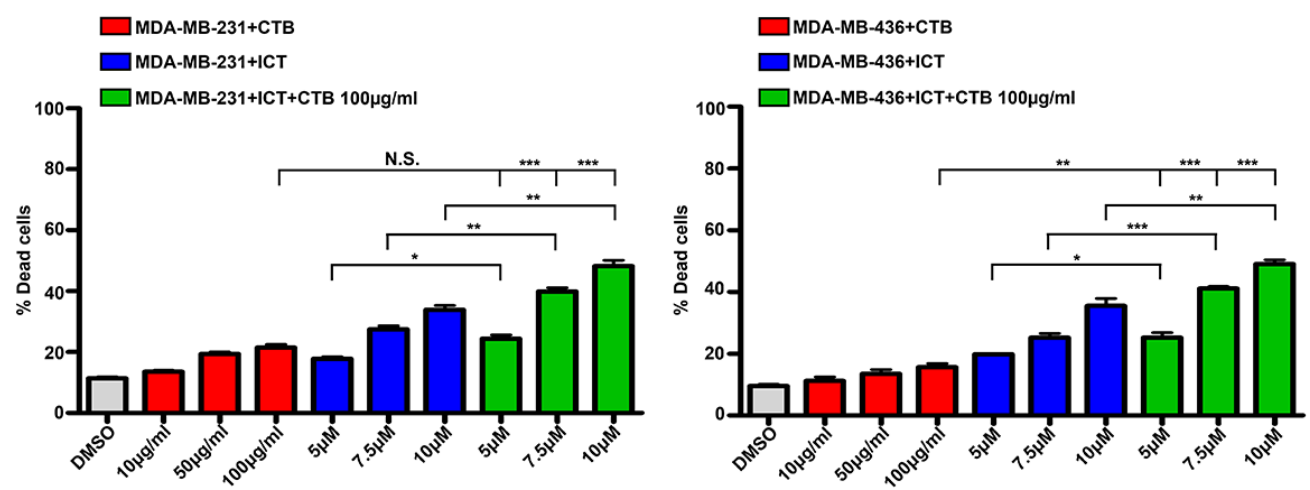

Figure 3. ICT and CTB co-treatment inhibits the proliferation and induce the apoptosis of TNBC cells. (A) Cell numbers (\% of control) of MDA-MB-231 and MDA-MB-436 cells compared between CTB $(1,5,10,50$ and $100 \mu \mathrm{g} / \mathrm{ml})$, ICT $(1,2.5,5,7.5$ and $10 \mu \mathrm{M})$ and CTB $(100 \mu \mathrm{g} / \mathrm{ml})+\mathrm{ICT}(1,2.5,5,7.5$ and $10 \mu \mathrm{M})$ treatment for 7 days. (B and C) Apoptosis assay performed using MDA-MB-231 and MDA-MB-436 cells treated with CTB (10,50 and $100 \mu \mathrm{g} / \mathrm{ml}), \mathrm{ICT}(5,7.5$ and $10 \mu \mathrm{M})$ and CTB $(100 \mu \mathrm{g} / \mathrm{ml})+\mathrm{ICT}(5,7.5$ and $10 \mu \mathrm{M})$ treatment for $24 \mathrm{~h}$. Data presented as mean \pm SD obtained from three independent experiments. ${ }^{*} \mathrm{P}<0.05,{ }^{* *} \mathrm{P}<0.01$ and ${ }^{* * *} \mathrm{P}<0.001$. CTB, cetuximab; ICT, icaritin; TNBC, triple-negative breast cancer.

cells. The mice were divided into 4 groups: Control, cetuximab, icaritin and cetuximab + icaritin (Fig. 4A and B). Cetuximab monotherapy was ineffective in MDA-MB-231 xenografts [tumor doubling time (TDT) $=12 \pm 2$ days, N.S.] compared with the control (TDT $=12 \pm 3$ days, $\mathrm{P}=0.556$ ) and icaritin monotherapy (TDT $=21 \pm 3$ days, $\mathrm{P}<0.001$; Fig. $4 \mathrm{~A}$ ) groups. The combined therapy induced a significant reduction in the tumor growth of MDA-MB-231 xenografts compared with cetuximab $(\mathrm{P}<0.001)$ or icaritin $(\mathrm{P}<0.001)$ monotherapy. Similar results could be observed in the xenografts derived from the MDA-MB-436 cell line (Fig. 4B). These results indicated that the combination of cetuximab and icaritin exhibited greater therapeutic effects compared with those elicited by cetuximab monotherapy or icaritin monotherapy.

\section{Discussion}

The EGFR regulates the development of epithelial tissue and maintains homeostasis. The EGFR is a driver of tumorigenesis in lung cancer, BC and glioblastoma (31). Inappropriate activation of the EGFR in cancer results mainly from amplifications and point mutations at the genomic locus (32). Experimental and clinical studies $(11,33)$ have suggested that EGFR expression in TNBC is higher compared with other 
A
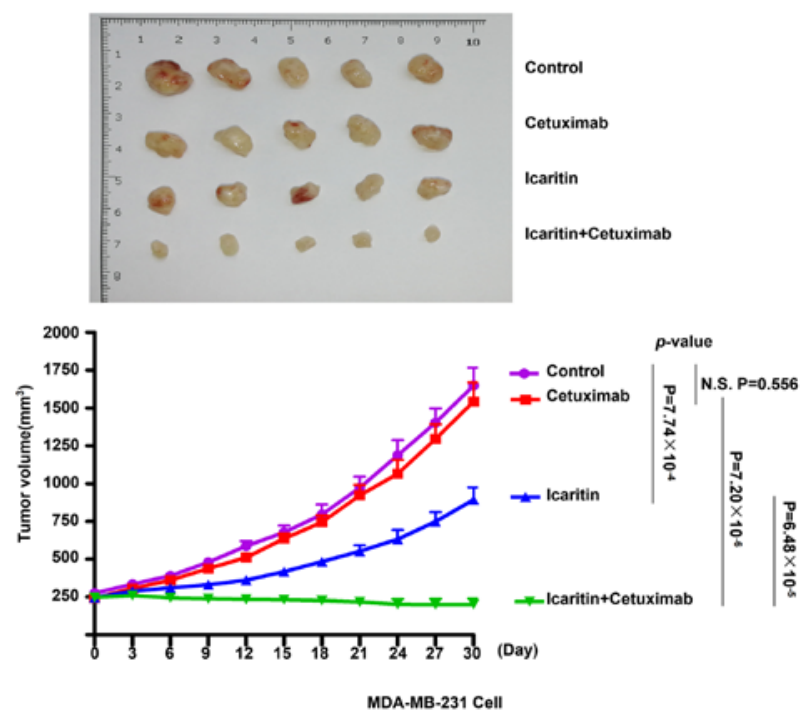

B
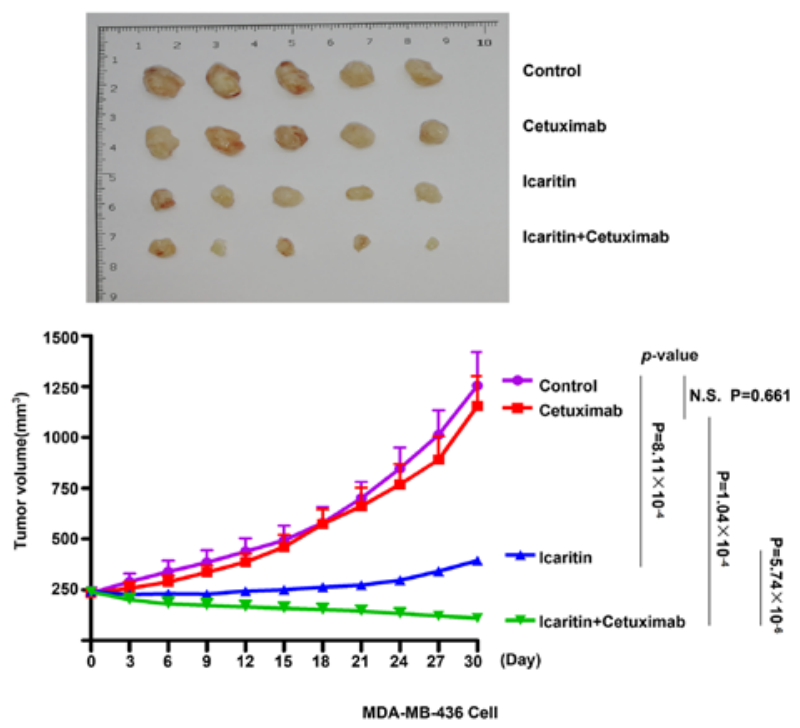

Figure 4. Xenograft mouse models derived from MDA-MB-231 and MDA-MB-436 cell lines treated with cetuximab monotherapy, icaritin monotherapy or cetuximab + icaritin. After the xenografts reached 6-8 $\mathrm{mm}$ in diameter, the mice were grouped randomly ( 5 mice/group) and injected (i.v.) with control, $\mathrm{NaCl}, 0.9 \%$; cetuximab, $2 \mathrm{mg} / \mathrm{kg} /$ week; icaritin, $50 \mathrm{mg} / \mathrm{kg} /$ week or cetuximab + icaritin, equivalent dose/week to treat (A) MDA-MB-231 and (B) MDA-MB-436 tumors. Tumor diameter was measured every 3 days. The xenografts and growth curves of tumors are displayed.

subtypes of BC, and that EGFR expression is associated with a poor prognosis, the 5 -year disease free survival (DFS) for EGFR-positive and EGFR-negative patients were 69.0\% and $83.8 \%$, respectively. DFS was significantly poorer for the EGFR-positive patients ( $\mathrm{HR}=2.11, \mathrm{P}=0.011)$ (34). Thus, EGFR inhibition is a promising approach against TNBC. Although, a variety of EGFR inhibitors have been developed, clinical studies have reported that the use of cetuximab alone in the treatment of patients with TNBC did not achieve the expected results, and most TNBC patients exhibit sustained activation of the PI3K/AKT signaling pathway downstream of the EGFR, suggesting that most had alternate mechanisms for pathway activation (35).
Previously, Zhang et al (36) reported that E2 $\beta$-stimulated proliferation of ER-negative BC cells is through a novel variant of the ER, ER- $\alpha 36$. It has also been demonstrated that E2 $\beta$ induced the physical interaction between ER- $\alpha 36$ and Src, and consequently, the auto-phosphorylation of Src-Y416 in ER-negative BC cells (37). In the present study, ER- $\alpha 36$ was upregulated in TNBC cell lines, and it was demonstrated that E2 $\beta$ serves an important role in activating the downstream PI3K/AKT signaling pathway by binding to ER- $\alpha 36$. These results are consistent with those of Tsai et al (38) who reported that E2 $\beta$ could induce PI3K/AKT phosphorylation in MDA-MB-231 ER-negative cells. Friedl et al (39) reported that the malignant growth of MD-MB-231 cells was stimulated by estrogen in immunodeficient mice. Therefore, the role of estrogen may be beyond classical activation of ER signaling. These data suggest that non-genomic and mitogenic estrogen signaling is retained in TNBC cells (39). Therefore, knowing the specific signaling pathway is important for therapeutic strategies targeting ER- $\alpha 36$. The present study demonstrated that icaritin effectively downregulated the expression of ER- $\alpha 36$, inhibited TNBC cell proliferation and induced apoptosis. However, the present study did not demonstrate that the effects of icaritin on the proliferation and apoptosis of TNBC cells were directly due to ER- $\alpha 36$ inhibition, future studies are required to ascertain this.

The present study demonstrated that EGF and estrogen activated the AKT signaling pathway. In vitro, MDA-MB-231 and MDA-MB-436 cells starved for $24 \mathrm{~h}$ in low-concentration serum and a phenol red-free environment, which has a weak estrogen-like effect, were used to investigate estrogen activation of the AKT signaling pathway. Cetuximab alone inhibited the activation of the AKT signaling pathway induced by EGF. In mice, the presence of endogenous estrogen activated the AKT signaling pathway, therefore, cetuximab alone was not sufficient to inhibit the activation of the AKT signaling pathway and tumor growth. This result was consistent with the hypothesis of an AKT bypass activation mechanism by the ER- $\alpha 36$ mediated rapid estrogen signaling pathway in TNBC cells.

In summary, the existence of ER- $\alpha 36$-mediated rapid estrogen signaling bypass activation AKT signaling pathway was demonstrated in TNBC cells. This ER- $\alpha 36$ mediated rapid estrogen signaling pathway is one of the mechanisms for the resistance of TNBC cells to EGFR-targeted therapy. It was also revealed that the combination of the ER- $\alpha 36$ molecular inhibitor icaritin and the EGFR inhibitor cetuximab may more effectively inhibit the proliferation and promote the apoptosis of TNBC cells compared with either individual drug. The current data may help to develop novel therapeutic strategies against TNBC.

\section{Acknowledgements}

The authors would like to thank Dr Zhao-yi Wang (Department of Medical Microbiology and Immunology, Creighton University Medical School) for donating the plasmid and antibody.

\section{Funding}

This study was supported by grants from the National Key Research and Development Program of China (grant 
no. 2016YFA0202104), the National Natural Science Foundation of China (grant no. 81602730) and the Key Clinical Research Program of Southwest Hospital (grant nos. SWH2016ZDCX1005, SWH2017ZDCX1003 and SWH2019TD-01).

\section{Availability of data and materials}

The datasets used and/or analyzed during the current study are available from the corresponding author on reasonable request

\section{Authors' contributions}

LY and XZL acquired, analyzed and interpreted data and drafted the manuscript; XWQ, ZYY and RLC acquired data; SCY, LC and HJC analyzed and interpreted data, critically revised the manuscript for intellectual content, obtained funding and supervised the study; all authors read and approved the final version of the manuscript.

\section{Ethics approval and consent to participate}

The study protocol was approved by the Animal Care and Use Committee of the Third Military Medical University (Army Medical University, Chongqing, China).

\section{Patient consent for publication}

Not applicable

\section{Competing interests}

The authors declare that they have no competing interests.

\section{References}

1. DeSantis CE, Ma J, Goding Sauer A, Newman LA and Jemal A: Breast cancer statistics, 2017, racial disparity in mortality by state. CA Cancer J Clin 67: 439-448, 2017.

2. Lehmann BD, Bauer JA, Chen X, Sanders ME, Chakravarthy AB, Shyr Y and Pietenpol JA: Identification of human triple-negative breast cancer subtypes and preclinical models for selection of targeted therapies. J Clin Invest 121: 2750-2767, 2011.

3. Foulkes WD, Smith IE and Reis-Filho JS: Triple-negative breast cancer. N Engl J Med 363: 1938-1948, 2010.

4. Haffty BG, Yang Q, Reiss M, Kearney T, Higgins SA, Weidhaas J, Harris L, Hait W and Toppmeyer D: Locoregional relapse and distant metastasis in conservatively managed triple negative early-stage breast cancer. J Clin Oncol 24: 5652-5657, 2006.

5. Dent R, Trudeau M, Pritchard KI, Hanna WM, Kahn HK, Sawka CA, Lickley LA, Rawlinson E, Sun P and Narod SA: Triple-negative breast cancer: Clinical features and patterns of recurrence. Clin Cancer Res 13: 4429-4434, 2007.

6. Carey LA, Dees EC, Sawyer L, Gatti L, Moore DT, Collichio F, Ollila DW, Sartor CI, Graham ML and Perou CM: The triple negative paradox: Primary tumor chemosensitivity of breast cancer subtypes. Clin Cancer Res 13: 2329-2334, 2007.

7. Hudis CA and Gianni L: Triple-negative breast cancer: An unmet medical need. Oncologist 16 (Suppl 1): S1-S11, 2011.

8. Chang-Qing Y, Jie L, Shi-Qi Z, Kun Z, Zi-Qian G, Ran X, Hui-Meng L, Ren-Bin Z, Gang Z, Da-Chuan Y and Chen-Yan Z: Recent treatment progress of triple negative breast cancer. Prog Biophys Mol Biol, Nov 21, 2019 (Epub ahead of print).

9. Troyer KL and Lee DC: Regulation of mouse mammary gland development and tumorigenesis by the ERBB signaling network. J Mammary Gland Biol Neoplasia 6: 7-21, 2001.

10. Kumar R and Wang RA: Protein kinases in mammary gland development and cancer. Microsc Res Tech 59: 49-57, 2002.
11. Nielsen TO, Hsu FD, Jensen K, Cheang M, Karaca G, Hu Z, Hernandez-Boussard T, Livasy C, Cowan D, Dressler L, et al: Immunohistochemical and clinical characterization of the basal-like subtype of invasive breast carcinoma. Clin Cancer Res 10: 5367-5374, 2004.

12. Corkery B, Crown J, Clynes M and O'Donovan N: Epidermal growth factor receptor as a potential therapeutic target in triple-negative breast cancer. Ann Oncol 20: 862-867, 2009.

13. Park HS, Jang MH, Kim EJ, Kim HJ, Lee HJ, Kim YJ, Kim JH, Kang E, Kim SW, Kim IA and Park SY: High EGFR gene copy number predicts poor outcome in triple-negative breast cancer. Mod Pathol 27: 1212-1222, 2014.

14. Masuda H, Zhang D, Bartholomeusz C, Doihara H, Hortobagyi GN and Ueno NT: Role of epidermal growth factor receptor in breast cancer. Breast Cancer Res Treat 136: 331-345, 2012.

15. Gelmon K, Dent R, Mackey JR, Laing K, McLeod D and Verma S: Targeting triple-negative breast cancer: Optimising therapeutic outcomes. Ann Oncol 23: 2223-2234, 2012.

16. Nakai K, Hung MC and Yamaguchi H: A perspective on anti-EGFR therapies targeting triple-negative breast cancer. Am J Cancer Res 6: 1609-1623, 2016.

17. Wang Z, Zhang X, Shen P, Loggie BW, Chang $Y$ and Deuel TF: Identification, cloning, and expression of human estrogen receptor-alpha36, a novel variant of human estrogen receptor-alpha66. Biochem Biophys Res Commun 336: 1023-1027, 2005.

18. Lee LM, Cao J, Deng H, Chen P, Gatalica Z and Wang ZY: ER-alpha36, a novel variant of ER-alpha, is expressed in ER-positive and -negative human breast carcinomas. Anticancer Res 28: 479-483, 2008.

19. Shi L, Dong B, Li Z, Lu Y, Ouyang T, Li J, Wang T, Fan Z, Fan T, Lin B, et al: Expression of ER-\{alpha\}36, a novel variant of estrogen receptor $\{$ alpha\}, and resistance to tamoxifen treatment in breast cancer. J Clin Oncol 27: 3423-3429, 2009.

20. Wang ZY and Yin L: Estrogen receptor alpha-36 (ER- $\alpha 36)$ : A new player in human breast cancer. Mol Cell Endocrinol 418: 193-206, 2015.

21. Wang Z, Zhang X, Shen P, Loggie BW, Chang Y and Deuel TF: A variant of estrogen receptor- $\{$ alpha\}, hER- $\{$ alpha\}36: Transduction of estrogen- and antiestrogen-dependent membrane-initiated mitogenic signaling. Proc Natl Acad Sci USA 103: 9063-9068, 2006.

22. Yang XJ, Xi YM and Li ZJ: Icaritin: A novel natural candidate for hematological malignancies therapy. Biomed Res Int 2019: 4860268, 2019.

23. Hong J, Zhang Z, Lv W, Zhang M, Chen C, Yang S, Li S, Zhang L, Han D and Zhang W: Icaritin synergistically enhances the radiosensitivity of 4T1 breast cancer cells. PLoS One 8: e71347, 2013.

24. Li S, Priceman SJ, Xin H, Zhang W, Deng J, Liu Y, Huang J, Zhu W, Chen M, Hu W, et al: Icaritin inhibits JAK/STAT3 signaling and growth of renal cell carcinoma. PLoS One 8: e81657, 2013.

25. Zhu JF, Li ZJ, Zhang GS, Meng K, Kuang WY, Li J, Zhou XF, Li RJ, Peng HL, Dai CW, et al: Icaritin shows potent anti-leukemia activity on chronic myeloid leukemia in vitro and in vivo by regulating MAPK/ERK/JNK and JAK2/STAT3/AKT signalings. PLoS One 6: e23720, 2011.

26. Wang X, Zheng N, Dong J, Liu L and Huang J: Estrogen receptor- $\alpha 36$ is involved in icaritin induced growth inhibition of triple-negative breast cancer cells. J Steroid Biochem Mol Biol 171: 318-327, 2017.

27. Brinkley BR, Beall PT, Wible LJ, Mace ML, Turner DS and Cailleau RM: Variations in cell form and cytoskeleton in human breast carcinoma cells in vitro. Cancer Res 40: 3118-3129, 1980.

28. Cailleau R, Young R, Olive M and Reeves WJ Jr: Breast tumor cell lines from pleural effusions. J Natl Cancer Inst 53: 661-674, 1974.

29. Chavez KJ, Garimella SV and Lipkowitz S: Triple negative breast cancer cell lines: One tool in the search for better treatment of triple negative breast cancer. Breast Dis 32: 35-48, 2010.

30. Kang L and Wang ZY: Breast cancer cell growth inhibition by phenethyl isothiocyanate is associated with down-regulation of oestrogen receptor-alpha36. J Cell Mol Med 14: 1485-1493, 2010.

31. Normanno N, De Luca A, Bianco C, Strizzi L, Mancino M, Maiello MR, Carotenuto A, De Feo G, Caponigro F and Salomon DS: Epidermal growth factor receptor (EGFR) signaling in cancer. Gene 366: 2-16, 2006.

32. Sigismund S, Avanzato D and Lanzetti L: Emerging functions of the EGFR in cancer. Mol Oncol 12: 3-20, 2018. 
33. Perou CM, Sørlie T, Eisen MB, van de Rijn M, Jeffrey SS, Rees CA Pollack JR, Ross DT, Johnsen H, Akslen LA, et al: Molecular portraits of human breast tumours. Nature 406: 747-752, 2000.

34. Liu D, He J, Yuan Z, Wang S, Peng R, Shi Y, Teng X and Qin T: EGFR expression correlates with decreased disease-free survival in triple-negative breast cancer: A retrospective analysis based on a tissue microarray. Med Oncol 29: 401-405, 2012.

35. Carey LA, Rugo HS, Marcom PK, Mayer EL, Esteva FJ, Ma CX, Liu MC, Storniolo AM, Rimawi MF, Forero-Torres A, et al: TBCRC 001: Randomized phase II study of cetuximab in combination with carboplatin in stage IV triple-negative breast cancer. J Clin Oncol 30: 2615-2623, 2012.

36. Zhang X, Ding L, Kang L and Wang ZY: Estrogen receptor-alpha 36 mediates mitogenic antiestrogen signaling in ER-negative breast cancer cells. PLoS One 7: e30174, 2012.
37. Zhang XT, Ding L, Kang LG and Wang ZY: Involvement of ER- $\alpha 36$, Src, EGFR and STAT5 in the biphasic estrogen signaling of ER-negative breast cancer cells. Oncol Rep 27: 2057-2065, 2012.

38. Tsai EM, Wang SC, Lee JN and Hung MC: Akt activation by estrogen in estrogen receptor-negative breast cancer cells. Cancer Res 61: 8390-8392, 2001.

39. Friedl A and Jordan VC: Oestradiol stimulates growth of oestrogen receptor-negative MDA-MB-231 breast cancer cells in immunodeficient mice by reducing cell loss. Eur J Cancer 30A: 1559-1564, 1994.

This work is licensed under a Creative Commons Attribution-NonCommercial-NoDerivatives 4.0 International (CC BY-NC-ND 4.0) License. 